This is an electronic reprint of the original article. This reprint may differ from the original in pagination and typographic detail.

Author(s): Siekkinen, Taru; Kuoppala, Kari; Pekkola, Elias; Välimaa, Jussi

Title: $\quad$ Reciprocal commitment in academic careers? : Finnish implications and international trends

Year: $\quad 2017$

Version:

Please cite the original version:

Siekkinen, T., Kuoppala, K., Pekkola, E., \& Välimaa, J. (2017). Reciprocal commitment in academic careers? : Finnish implications and international trends. European Journal of Higher Education, 7(2), 120-135.

https://doi.org/10.1080/21568235.2016.1248990

All material supplied via JYX is protected by copyright and other intellectual property rights, and duplication or sale of all or part of any of the repository collections is not permitted, except that material may be duplicated by you for your research use or educational purposes in electronic or print form. You must obtain permission for any other use. Electronic or print copies may not be offered, whether for sale or otherwise to anyone who is not an authorised user. 


\title{
Reciprocal commitment in academic careers? Finnish implications and international trends
}

Published online 17 Nov 2016 in: European Journal of Higher Education. http://dx.doi.org/10.1080/21568235.2016.1248990

Taru Siekkinen (corresponding author), the Finnish Institute for Educational Research, University of Jyväskylä

Kari Kuoppala, the School of Management, University of Tampere

Elias Pekkola, the School of Management, University of Tampere

Jussi Välimaa, the Finnish Institute for Educational Research, University of Jyväskylä

\begin{abstract}
This study explores the nature of reciprocal commitment in academic careers. The article is based on a survey conducted in autumn 2013 among fixed term employees at eight major universities in Finland $(\mathrm{N}=810)$. The analysis is focusing on researchers who have a doctoral degree and who are working on a fixed-term contract at their university $(\mathrm{n}=308)$. According to our study, researchers experience their working conditions are insecure and many of them have considered leaving their universities. Despite the fact that they find their work meaningful their uncertain and poor working conditions are related to their thoughts of leaving the university. In addition in many of the cases leaving the university is not a choice of the researcher - they wish they would not have to leave. Based on our findings, higher education institutions should carefully consider if both the benefits of fixed-term contracts and their transaction costs are related to academics' wellbeing and motivational issues. Our study highlights the importance of reciprocity and dialogue between employers and employees in the making of academic careers.
\end{abstract}

Keywords: academic career, academic work, reciprocity, commitment, trust.

\section{Introduction}

Working life and employment relations have become more uncertain, unpredictable, and riskier for employees. This development has been called the precarisation of work. Originally precarisation had its roots in the European social movement, where the workers felt they were left working and living without any stability or a safety net. The term and the phenomenon have now gained new content. Recent precarisation is caused, for instance, by the development of labour markets where the organisations are seeking more economic efficiency, causing substantial lay-offs, and increasing the use of temporary employment. In addition, precarious work has become pervasive, meaning that also professional and managerial jobs are becoming precarious in many sectors. (Kalleberg 2009.)

In Europe, careers in academia are considered precarious because short and fixed-term employment contracts, especially during the early stage of a career. In addition, funding is often competitive and it is common that individual academics have the responsibility to obtain their own funding. Acquiring funding and developing an academic career suggest that individual academics need to have persistence for their work 
(Brechelmacher et al. 2015; Huisman et al. 2002; In Finland: Hakala 2009; Pekkola 2014; Kuoppala et al 2015.) This has created a situation in which the uncertainty at the beginning of an academic career has been said to decrease its attractiveness in Europe (Huisman et al. 2002; Aarrevaara et al. 2012, Pekkola 2010, European Commission 2008)).

The changes in higher education, higher education institutions (HEIs), and higher education systems, have changed the role of the academic profession as well (e.g. Hyde et al. 2013; Kogan \& Teichler 2007). However, this is nothing new because the academic profession is responsive by its nature, and adopts to external changes. (Musselin 2007, 175). Yet, external factors changing the profession have varied over time. Currently, managerial ideology is becoming a dominant discourse and factor for defining universities and their problems - including the role of academics (Hyde et al. 2013; Slaughter and Leslie 1997). Neo-liberal policies have pushed universities to act more like enterprises, and university researchers are becoming more like state-supported entrepreneurs than traditional academics (Slaughter and Leslie 1997). In Finland, the new university act in 2009 strengthened the trend of managerialism. Consequently, universities have become autonomous financial entities and the status of the employees has changed from civil servants to employees. (Välimaa 2011.)

Regardless of the changes in policy environment, the universities continue to be both organisations and academic communities constituted by their members', i.e. individual academics. Thus, commitment is a key concept in our study due to its central importance for the academic communities and making of academic careers in new, precarious institutional environment. We use commitment in order to focus on the duality of the career process, the two sides of a career, namely the one of an employee and the one of an employer. We call this interplay and two-sided commitment 'reciprocal commitment'. Focusing on academics is important because most of the research on commitment falls under a broad category of work-life research, mainly within the disciplines of sociology, social psychology, psychology, and business economics (e.g. Baruch 1998; Cohen 2007; Feldt et al. 2016; Mamia and Lähteenmäki 2007; Meyer and Allen 1991). Commitment in academic work in the field of higher education studies is a much less problematised and studied topic.

Our empirical data was collected from university employees. Employers' commitment will therefore be analysed through employees' answers to the survey. This brings some limitations to the study. However, we would like to emphasise that the purpose of this article is not to measure the level of the employees' or employers' commitment. The aim of this article is to consider the nature of the commitment in academic careers from different perspectives, focusing more on the employees' point of view. The perceptions of the survey provide us an avenue to understand the phenomenon more in depth.

\section{Careers in the context of academia}

As a starting point for our working definition of an 'academic career', we adopt the classical definition of a career by van Maanen $(1977,8)$ because it combines all relevant factors: individuals, (higher education) institutions, and societal change. According to van Maanen: 
Career reflects the relationship between people and the providers of official position, namely, institution or organisations, and how these relationships fluctuate over time. Seen in this way, the study of careers is the study of both individual and organisational change as well as of societal change.

The precarious working conditions of researchers in their early careers are well known. In addition, the fixed-term contracts and high competition for funding and available posts at every career stage are making academic careers insecure and difficult to obtain and pursue. Academic career needs ambition, persistence and willingness to take risks, for example. (Brechelmacher et al. 2015; see also Huisman et al. 2002; Pekkola et al. 2012).

There have been made attempts to restructure obscure academic career paths. The European Commission has launched the European Charter for Researchers and a Code of Conduct for the Recruitment of Researchers and later the Human Resources Strategy for Researchers (HRS4R) aiming to support it (European Commission 2015). The HRS4R policy has also been widely implemented in Finnish higher education (Siekkinen et al. 2015). In addition, the European Science Foundation and Finnish Ministry of Education and Culture have recommended universities a four-stage researcher career model with the hope of making academic careers more transparent (European Science Foundation 2009, 18; MEC 2008).

According to a recent evaluation of the Finnish four-stage career model (Välimaa et al. 2016), the four-stage career model is based on the presumption that academic careers should follow a linear upward progress. However, the reality does not respect the model because there is a large group of researchers in academia, mainly project researchers, who are not included in the model. Their careers are quite fragmented because they consist of various fixed-term, project-based contracts (Välimaa et al. 2016). In addition, many European and increasingly also Finnish universities have introduced different kinds of tenure-track systems in order offer a clearer career path towards permanent, tenured employment (Brechelmacher et al. 2015, 23; Välimaa et al. 2016; Pietilä 2015). However, despite the fact that tenure track models are strategically important they are often more or less insignificant for vast majority of academics and their career progression. In Finnish universities only $5 \%$ of all open positions are tenure track positions in general (Välimaa et al. 2016).

In contemporary working life, careers are often described as boundaryless and employees more as entrepreneurs than traditional workers. Stahl et al. (2002) found out that employees prioritised more their personal professional development than the stable career prospects in their current working organisation. (Stahl et al 2002.) It seems that academic careers might also follow this trend (Kaulisch and Enders 2002) because of the increasing mobility of faculty members, the growing amount of part-time and adjunct staff, and the decreasing use of alternative contracts for permanent positions. At the same time, however, academics may be increasingly bound to their organisations. Recent university policies and practices emphasise the shift from collegial and professional models of governance to management models that entwine the activities of academics' more closely to the interests and needs of their organisations (Kaulisch and Enders 2005, 139; Harley et al. 2004, Farnham 1999). 
The increased output-based steering and evaluation (Musselin 2013; Pekkola 2014; Kallio \& Kallio 2014) have also strengthened the increased importance of the organisations in steering academic work, careers and performances. In addition, academics working in universities have been described more as individual entrepreneurs as they are increasingly responsible for finding the funding for their research. This development is connected with the trends of academic capitalism (Slaughter \& Leslie 1997) and related to the entrepreneurial ethos that is becoming common in universities and thus to the construction of the entrepreneurial university (Clark 1998, 2004; Etzkowitz 2013).

We argue that academic careers have two main components which need to be analysed simultaneously: organisational and individual. Following the definition by Baruch (2004, 3), careers are made by individuals but an individual's work and career is planned and managed by an organisation. The organisation provides the positions and sets the qualifications for them, as well as establishes interrelationships between positions and mechanisms for how employees can navigate in them (Baruch 2013). Musselin $(2013,26)$ notes that academics always have developed their activities within organisational structures, that is, in universities. Therefore, in the career domain, the distinction between the organisational and individual dimensions is not clear-cut. In academic careers, for example, the individual and organisational goals more or less overlap when career success and proceeding in a career are discussed.

Herriot and Pemberton (1996, 760-764) describe several types of relationships between individuals, organisations, and organisational environments in their contractual model of careers (Figure 1 below illustrates only a few of the many relationships in the actual model).

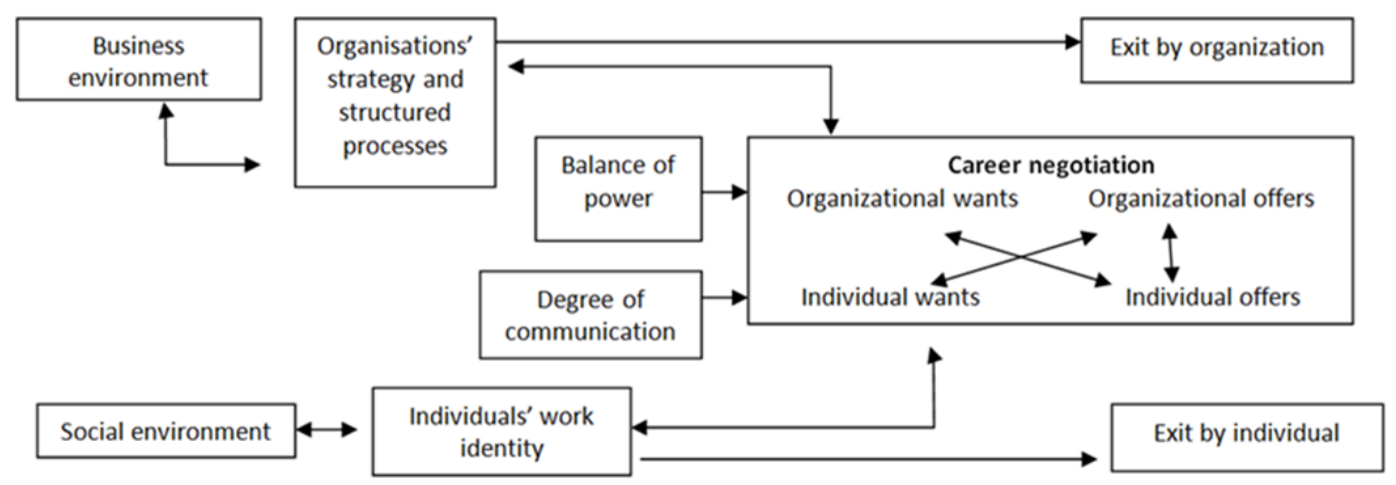

Figure 1. Herriot and Pemberton's contractual model of careers (part of the model) (Herriot and Pemberton 1996, 760)

For this study, the most interesting relationships in the context of academic careers are those between the employees and the organisation and, the one between the organisation and its strategy, structure, processes, and environment, as well as the relationship between individuals and their social environment and work identity. In 'career negotiation', there are four relationships: 'organisational wants', 'organisational offers', 'individual wants', and 'individual offers'. Changes in wants and/or offers will change the whole negotiation process. In addition, changes in the business environment will lead to changes in the 'wants' and/or 'offers' of an organisation. Moreover, changes in 
the social environment or work identity will lead to changes in the 'wants' and/or 'offers' of an individual.

In the academic context, the career negotiation during the recruitment process from the employer's side means finding the right person for the specific position. Departments emphasise documented achievements that mainly indicate the research but also teaching outputs of the candidate. That indicates offers from the employees' side. However, being a good researcher is not enough, although employers' wants mostly are related to them; the candidate should be a good colleague and they should be able to integrate into the department. (Musselin 2010, 112; Välimaa et al. 2016.) The career negotiation is not taking place only in the recruitment process, it consists of repeated discussions that take into consideration the changing contexts (Herriot and Pemberton 1996, 764). In addition, the "wants" of both sides can be too demanding and that can be a reason for ending the employee - employer relationship. Job demands in academia are often considered high and many academics have difficulties to balance between their work and family duties (e.g. Kinman and Jones 2008).

\section{Commitment}

Commitment is a widely studied phenomenon and a commonly used concept in worklife research because a number of studies have shown that commitment is related to many factors of well-being at work (e.g. Meyer and Allen 1991; Hakanen and Koivumäki 2014). Commitment is considered to be a stabilising force that gives a direction to one's actions; that is, it binds individuals to a course of action (Meyer and Herscovitch 2001, 301). However, regarding commitment, there are several different concepts that refer to the same or almost same phenomenon - though with different aspects. For example, 'job involvement', 'work engagement', and 'occupational/career commitment' refer to the employees' commitment to their work or career (Meyer and Allen 1991; Cohen 2003; Hakanen, Schaufeli, and Ahola 2008; Meyer and Herscovitch 2001). Perhaps the most studied aspect is 'organisational commitment' (e.g. Baruch 1998; Cohen 2007; Meyer and Allen 1991).

In principle, the nature of organisational commitment is that a person has a sense of commitment to her or his working organisation. It can "involve identification with, tendency to stay in, and willingness to exert efforts for the organisation” (Baruch 1998). However, Baruch emphasises that commitment is a dual type phenomenon, reciprocity in relationships where trust is a significant basis. Organisations are complex systems, which are operating towards a common goal, and organisational commitment is actually making this goal common. If organisations succeed to create and maintain the reciprocal commitment, it benefits both sides: the organisations (more loyalty, improved moral, stronger loyalty) and the employee (higher job satisfaction, a better quality of working life) and these outcomes can lead to a higher level of performance and effectiveness. (Baruch 1998.)

However, organisational commitment has been and is still changing. According to Baruch (1998), organisations have forsaken their commitment towards their employees and because of that there is no stable basis for reciprocal commitment. Today, organisations are in a competition which means focusing more on efficiency rather than on employee relationships. "It is no longer 'people are our most important asset', but 
'fewer people are our most important asset'”. As a conclusion Baruch states that the decision-makers in organisations should acknowledge that the level of organisational commitment will collapse if they prioritise only economic matters above all else. (Baruch 1998.)

\section{Commitment and academic careers}

In the context of academic careers, the organisational commitment that is reciprocal by its nature (Baruch 1998) is a rather challenging topic to study. First of all, it is often unclear what the common goal of a university is as an organisation that is porously loosely coupled (Birnbaum 1988) and in which the work is structured clearly according to two principles: disciplinary (or scientific) fields and organisations (enterprises) (Clark 1983). European academics have traditionally defined their academic identities in relation to their disciplinary traditions and (international) academic communities, rather than in relation to their universities, as seems to be the case in North America (Välimaa 1998). Therefore, their commitment to academic work is related more to their scientific communities than to universities as organisations. In addition, the rewards that academics find noteworthy are usually not organisational but instead they value scientific merits and reputation (Kaulisch and Enders 2005).

The second possible form of organisational commitment, according to Baruch, is the tendency to stay in the organisation (Baruch 1998). However, the career prospects in academia are commonly insecure and the working contracts are very short and fixedterm, at least in the beginning of an academic career (Brechelmacher 2015; In Finland: Kuoppala et al 2015). Academic researchers have different kinds of motives to continue working at certain universities; some are related to the work itself, some to the organisation, and some to private reasons. Although the academic staff members are encouraged to be mobile, staying in a faculty after attaining a doctoral degree ('academic inbreeding') is rather common, especially in smaller European nation states (e.g. Horta, Veloso, and Grediaga 2010). The third possible dimension of organisational commitment Baruch mentions is the willingness to exert efforts for the organisation. Academic work usually contains working extra hours (Kinman and Jones 2008) and what is needed is persistence and ambition, for example, in order to obtain and proceed in an academic career (Brechelmacher et al 2015).

Employers' commitment to their employees is a less studied topic. It is possible to examine empirically through the length of employment contracts and the salary levels. However, these two factors illustrate the phenomenon only narrowly, whereas the real commitment of an employer is more challenging to measure. In the context of academia, the employers' commitment is strong when the employer invests a great deal to an individual researcher or research group. In universities, employees are increasingly seen as a strategic resource, for example in the form of tenure track recruitments, which are also a means for profiling in universities (Pietilä 2014). In universities, the employees are particularly important: they hold and use the special knowledge (Rasmussen 2015) and they are connected to all central activities in universities (Baruch 2013; Kogan et al 1994.)

In the context of academic career, the question of employers' commitment is a challenging one. First of all, it is often unclear who the employer in academia is? In Finland, the university as an organisation is officially the employer but, concerning the 
reciprocal relationship, the actual employer representative situates in lower-level academic units. Often it is the faculty dean who represents the employer but not in all universities and not always for all employees. However, inside the faculty there can be many persons who are in the position of a manager: dean, head of department, professor, or research group head. According to a recent study on academic careers in Finland (Välimaa et al. 2016), for project researchers the employer often is represented by the recruiting professor whereas for lecturers and senior researchers it is represented by a dean or head of department. It is also possible that, in the university context, employees consider their employer to be a faceless unit located in the central administration.

Another important notion is that there can be many "employers" in universities as loosely coupled and open systems. Professors may be very committed to her/his employees. The head of department or the dean may be acting more as an official employer. On the other hand, an individual researcher can be directly responsible for a funding agency and only loosely coupled with a university or a unit. The commitments of these "representatives of employers" commitments, motivations, and interests may differ, overlap and conflict. Therefore, one meets a challenging question when commitment is operationalised into a research question.

Kaulisch and Enders (2005) have emphasised the complexity and the dynamic nature of academic careers, which relates to the nature of academic work: academics act simultaneously in different social contexts. In addition, there are features that affect academic careers and characterise them: Firstly, the institutional embeddedness in the science system and the susceptibility to academic discipline; secondly, the different national settings and their various cultural contexts; thirdly, changing organisational contexts of academic work and the implications of global trends towards managerialism and marketization of academic careers (Kaulisch and Enders 2005). In this article, we presume that an individual's career forms and proceeds in relation to those aspects. However, we emphasise the interaction and reciprocal commitment between the individual and the organisation, taking into account the cultural context and global trends as well.

\section{Data and methods}

The data for this study comes from on an electronic survey conducted in 2013 (see Kuoppala et al. 2015). The survey comprised many quantitative but also a few qualitative questions related to academic work and careers. The target group of the survey were academic staff working at eight Finnish universities, mainly on fixed-term contracts. The survey had overall 810 respondents, with a response rate of 23 per cent. Regardless of the rather moderate response rate, the respondents represented all scientific fields, both genders, and different age groups. In this study we explore only the doctoral students, project researchers, postdoctoral researchers, university researchers and lecturers in the data $(\mathrm{n}=658)$ (see Table 1.).

Table 1. Survey respondents. 


\begin{tabular}{|l|l|c|c|}
\hline & & n & $\%$ \\
\hline & & 658 & $100 \%$ \\
\hline Title & University researcher / lecturer PhD & 104 & $16 \%$ \\
\hline & Postdoctoral researcher/ researcher / project researcher PhD & 204 & $31 \%$ \\
\hline & Doctoral student / project researcher M.A & 350 & $53 \%$ \\
\hline Age & $25-30$ & 135 & $21 \%$ \\
\hline & $31-40$ & 354 & $54 \%$ \\
\hline & $41-50$ & 116 & $18 \%$ \\
\hline & $51-67$ & 53 & $8 \%$ \\
\hline Gender & Female & 342 & $52 \%$ \\
\hline & Male & 313 & $48 \%$ \\
\hline Field & Bioscience, geography, ecology, agriculture and forestry & 81 & $13 \%$ \\
\hline & Humanities & 76 & $12 \%$ \\
\hline & Natural sciences & 116 & $18 \%$ \\
\hline & Medical and health science & 81 & $13 \%$ \\
\hline & Technology & 161 & $25 \%$ \\
\hline & Social sciences & 131 & $20 \%$ \\
\hline
\end{tabular}

Our main interest focuses on researchers who have a doctoral degree and who are working on a fixed-term contract, mainly as postdoctoral researchers $(n=204,30 \%)$ and university researchers and lecturers $(\mathrm{n}=104,16 \%)$. These groups are central to our study because they have gained doctoral degrees and accomplished university employment; however, they have still not attained a permanent position. To study this group, it is good to compare them with the group of doctoral students and project researchers who were $53 \%$ of all respondents $(n=350)$. In our quantitative analysis, we will compare these three groups using cross tabulation.

We also explore one qualitative question and eight quantitative questions from the survey related to the researchers' working conditions (Table 2). Through these questions we explore the data on reciprocal commitment experienced by researchers.

Table 2. Survey questions. 


\begin{tabular}{|c|c|c|}
\hline Claim & Response / scale & Measuring \\
\hline $\begin{array}{l}\text { Length of the current working } \\
\text { contract }\end{array}$ & $\begin{array}{l}\text { Respondents marked the length of } \\
\text { their current working contract: } \\
\text { years and months. }\end{array}$ & $\begin{array}{l}\text { The commitment of the } \\
\text { employer** }\end{array}$ \\
\hline $\begin{array}{l}\text { The continuation of my career at } \\
\text { the university is likely }\end{array}$ & $1-5^{*}$ & The reciprocal commitment** \\
\hline $\begin{array}{l}\text { My salary is justified in relation } \\
\text { to my tasks and my personal } \\
\text { work performance }\end{array}$ & $1-5^{*}$ & $\begin{array}{l}\text { The commitment of the } \\
\text { employer** }\end{array}$ \\
\hline I feel my work is meaningful & $1-5^{*}$ & The commitment of the employee \\
\hline I feel my work as a vocation & $1-5^{*}$ & The commitment of the employee \\
\hline $\begin{array}{l}\text { I identify myself as a member of } \\
\text { the scientific community }\end{array}$ & $1-5^{*}$ & $\begin{array}{l}\text { The commitment of the } \\
\text { employee** }\end{array}$ \\
\hline $\begin{array}{l}\text { I identify myself as a member of } \\
\text { my work unit }\end{array}$ & $1-5^{*}$ & The reciprocal commitment** \\
\hline $\begin{array}{l}\text { 1. Have you considered working } \\
\text { elsewhere than at a university? }\end{array}$ & $\begin{array}{l}\text { a. No, I have not } \\
\text { b. Yes, I have considered } \\
\text { working elsewhere } \\
\text { c. Yes, I have made concrete } \\
\text { actions to work outside the } \\
\text { university }\end{array}$ & $\begin{array}{l}\text { The commitment of the } \\
\text { employee. }\end{array}$ \\
\hline $\begin{array}{l}2 . \text { Why have you considered } \\
\text { working elsewhere? }\end{array}$ & Open question & The reciprocal commitment** \\
\hline
\end{tabular}

* Completely disagree, disagree, neither disagree nor agree, agree, completely agree.

** All the questions were asked from the employees, the answers are their perceptions of the questions.

Our data analysis is a secondary analysis and therefore we used it for a different purpose than for what it was initially commissioned (Dale et al. 2009). The data were collected by a project to exploring fixed-term researchers' working conditions (Kuoppala et al. 2015). Thus, originally it was not intended for a study on commitment. Regardless of these challenges, typical with secondary data, the analysis can be done in a reliable way because we know the context and the data in depth and can reliably assess the validity of the indicators.

Moreover, we studied how confident the researchers were considering the continuation of their careers at the university and how these perceptions were related to how meaningful they find their work. Two-way Analysis of Variance (ANOVA) (see table 4) made the analysis. "Meaningfulness of work" was formed with an aggregated variable (Cronbach's Alpha .702) that contained three questions from the survey:

- I find my work is meaningful $(M 4,17, S D 0,915)$

- I consider my work as a vocation $(M 3,73, S D 1,161)$

- Research and improving my research skills are important to me in my work ( $M$ 4,52, $S D$ 0,722)

\section{Findings}

\subsection{Working conditions and reciprocal commitment of fixed-term researchers}

We considered the working conditions and the reciprocal commitment of Finnish fixedterm academics in the data through six claims that can be seen in Table 3 below.

Table 3. The commitment and the working conditions of the employees in the survey data. 


\begin{tabular}{|c|c|c|}
\hline & Mean & Std. Dev. \\
\hline \multicolumn{3}{|c|}{$\begin{array}{l}\text { The continuation of my career at the university is likely } \\
(n=600, p>.05)\end{array}$} \\
\hline University researcher / lecturer $(\mathrm{PhD})$ & 3,07 & 1,32 \\
\hline Postdoctoral researcher & 2,81 & 1,26 \\
\hline Doctoral student, project researcher (M.A) & 2,78 & 1,18 \\
\hline \multicolumn{3}{|c|}{$\begin{array}{l}\text { My salary is justified in relation to my work tasks and my } \\
\text { personal work performance } \\
(n=637, p<.05)\end{array}$} \\
\hline University researcher / lecturer $(\mathrm{PhD})$ & 3,55 & 1,38 \\
\hline Postdoctoral researcher & 2,99 & 1,37 \\
\hline Doctoral student, project researcher (M.A) & 2,91 & 1,34 \\
\hline \multicolumn{3}{|l|}{$\begin{array}{l}\text { I feel my work is meaningful } \\
(\mathrm{n}=643, \mathrm{p}<.05)\end{array}$} \\
\hline University researcher / lecturer $(\mathrm{PhD})$ & 4,42 & 0,64 \\
\hline Postdoctoral researcher & 4,19 & 0,96 \\
\hline Doctoral student, project researcher (M.A) & 4,08 & 0,94 \\
\hline \multicolumn{3}{|l|}{$\begin{array}{l}\text { I feel my work as a vocation } \\
(\mathrm{n}=625, \mathrm{p}<.001)\end{array}$} \\
\hline University researcher / lecturer $(\mathrm{PhD})$ & 3,99 & 1,06 \\
\hline Postdoctoral researcher & 3,98 & 1,1 \\
\hline Doctoral student, project researcher (M.A) & 3,53 & 1,19 \\
\hline \multicolumn{3}{|c|}{$\begin{array}{l}\text { I identify myself as a member of the scientific community } \\
(n=648, p<.001)\end{array}$} \\
\hline University researcher / lecturer $(\mathrm{PhD})$ & 4,31 & 1,05 \\
\hline Postdoctoral researcher & 4,02 & 1,03 \\
\hline Doctoral student, project researcher (M.A) & 3,71 & 1,11 \\
\hline \multicolumn{3}{|l|}{$\begin{array}{l}\text { I identify myself as a member of my work unit } \\
(n=646, p>05)\end{array}$} \\
\hline University researcher / lecturer $(\mathrm{PhD})$ & 4,22 & 1,12 \\
\hline Postdoctoral researcher & 3,97 & 1,05 \\
\hline Doctoral student, project researcher (M.A) & 4,04 & 1,02 \\
\hline
\end{tabular}

In Table 3, it can be seen that fixed-term researchers found their work meaningful and considered it as a vocation. Furthermore, they identified themselves as a member of the scientific community as well as of their work unit. However, they felt that the continuation of their career at university was rather unsure and some of them were unsatisfied with their salaries.

There found also differences between the employee groups. Younger academics found the continuation of their careers at the university more insecure than senior academics. As many as 40 per cent of all fixed-term postdoctoral researchers and university researchers/lecturers found the continuation of their university careers unlikely. We also asked in the survey what the length of their current working contract was. Among survey respondents, fixed-term researchers' contracts varied between a few months and over five years. Postdocs had shorter contracts, from a couple of months to two years, with only five per cent having contracts for more than five years, whereas compared with university researchers / lecturers, nearly one third of whom had a contract lasting for over five years. Both before and soon after attaining their doctoral degrees, researchers usually work with short fixed-term employment contracts and with external funding aiming to stabilise their positions within their university (Brechelmacher et al. 2015, In Finland: Välimaa et al 2016; Kuoppala et al 2015.)

Doctoral students were most unsatisfied with their salaries, whereas university researchers/lecturers were most satisfied. Almost 20 per cent of the postdocs and one 
third of the university researchers/lecturers completely agreed that their salaries were justified in relation to their tasks and their personal work performance. However, it is remarkable that the salary level of early-career researchers is low compared to the salaries earned in private business companies, which may be one of the facts decreasing the attractiveness of an academic career (Huisman et al. 2002).

Almost a half of all fixed-term researchers with a doctoral degree completely agreed with the claim about the meaningfulness of their work. In spite of some of its negative features, the employees' perceptions about the meaningfulness of their work and their feelings it as a vocation shows that work can be seen as personally significant. Indeed, 76 per cent of all fixed-term $\mathrm{PhD}$ researchers/lecturers in the data partially or completely agreed with the claim that 'research is my vocation'. Senior academics found their work more often as a vocation than younger academics.

The majority of the researchers identified themselves as members of the scientific community. Of the university researchers/lecturers 55 per cent and of postdoctoral researchers 37 per cent completely agreed with the claim. It is no surprise that in later career stages identification with the scientific community is greater: the collaboration with colleagues has lasted longer and networks with scientific communities have been built over a long time.

The majority of the researchers identified themselves also as a member of their work unit. Of postdoctoral researchers 34 per cent and of the university researchers/lecturers 53 per cent completely agreed with the claim. Interestingly, there are no major differences between the numbers of respondents identifying themselves with the scientific communities and with working units, considering the fact that especially postdocs' working contracts are often short and fixed-term. As was discussed before, researchers' commitments can focus on the scientific community and/or the university. These commitments are not mutually exclusive but rather coexisting feelings. The object of their commitment can also change during their academic career depending on their work tasks and responsibilities in their university or their working unit, and in the scientific communities.

\subsection{How do the employees' perceptions about continuation of their career influence how meaningful they find their work?}

We studied employees' perceptions about the continuation of their career at the university, and weather it had an effect on how meaningful they find their work.

Table 4. How the employees' perceptions about the continuation of their career at the university is related to how meaningful they found their work. Two-way analysis on variances (ANOVA). 


\begin{tabular}{|c|c|c|c|c|}
\hline \multicolumn{5}{|c|}{ The continuation of my career at the university is likely } \\
\hline & $\begin{array}{l}\text { Doctoral student / } \\
\text { Project Researcher } \\
\text { (M.A) } \\
\text { n=314 }\end{array}$ & \multicolumn{2}{|c|}{$\begin{array}{l}\text { Postdoctoral } \\
\text { Researcher } \\
\text { n=184 }\end{array}$} & $\begin{array}{c}\text { University } \\
\text { Researcher / Lecturer } \\
(\mathrm{PhD}) \\
\mathrm{n}=98\end{array}$ \\
\hline Mean & 2,78 & \multicolumn{2}{|c|}{2,81} & 3,07 \\
\hline Std. Deviation & 1,181 & \multicolumn{2}{|c|}{1,262} & 1,318 \\
\hline \multicolumn{5}{|c|}{ Meaningfulness of work } \\
\hline Mean & 4,01 & \multicolumn{2}{|c|}{4,26} & 4,33 \\
\hline Std. Deviation & 0,775 & \multicolumn{2}{|c|}{0,739} & 0,65 \\
\hline \multicolumn{3}{|c|}{ Two-way Analysis of Variance } & $\begin{array}{c}\text { df } \\
\text { (error) }\end{array}$ & Sig \\
\hline \multicolumn{4}{|c|}{ The meaningfulness of work * employee category } & $\mathrm{p}<.05$ \\
\hline \multicolumn{3}{|c|}{$\begin{array}{l}\text { The meaning fulness of work * the continuation of my } \\
\text { career at the university is likely }\end{array}$} & $4(581)$ & $\mathrm{p}<.001$ \\
\hline \multicolumn{3}{|c|}{$\begin{array}{l}\text { The continuation of my career at the university is likely* } \\
\text { the meaningfulness of work }{ }^{*} \text { employee category }\end{array}$} & $8(581)$ & $\mathrm{p}>.05$ \\
\hline
\end{tabular}

Based on the analysis we found out that researchers' perceptions on how meaningful they found their work differs by groups $(p<.05)$. All three groups considered work highly meaningful. In addition, researchers' perceptions considering the continuation of their career in university was related to the meaningfulness of work $(\mathrm{p}<.001)$. However, there was no significant relation between the meaningfulness of work and employees' groups and their perceptions about continuation of one's career in the university $(\mathrm{p}>.05)$.

\subsection{How many have considered leaving the university and why?}

All the employee respondents analysed in the data were working with a fixed-term contract. In their situation, the importance of having a 'plan B' is often needed or at least recognised. In the context of precarious academic work, it is not surprising that in the survey data 48 per cent of respondents had considered working elsewhere than at a university and 27 per cent had taken concrete actions towards working somewhere else. Still, 25 per cent of the respondents said they had not considered leaving the university. In spite of their short fixed-term contracts, some researchers may strongly believe their contract will continue, and that is why they had not considered leaving their university. In their study, Kinman and Jones (2008) found out that academics in the UK were moderately satisfied with their work. However, the satisfaction towards the working hours and salaries, for example, were lower. In their study, 48 per cent of the respondents stated that they had seriously considered leaving the university. (Kinman and Jones, 2008).

We asked the respondents to specify in open question section why they had considered leaving the university. Almost all the answers included reasons related to precarious working conditions (135 researchers provided answers: 96 postdocs, 32 university researchers, 7 university teachers/lecturers). These included both short fixed-term contracts and continuous competition for research funding and for few positions. Some researchers, however, also mentioned poor salaries and career progression opportunities, bad management, the need for change, or increasing institutional bureaucracy. We classified answers into four categories (researchers often mentioned reasons from more than one category): (1) precariousness ( $n=101)$, (2) poor appreciation and low salaries $(n=17),(3)$ career progression/need for change $(n=12)$ and (4) bad personnel policy and leadership, increasing bureaucracy and the change in the employment status of university employees $(n=7)$. We translated the original Finnish answers into English. 
According to the most of the open answers the employees described why precariousness would be the reason for leaving the university.

My life situation is changing and I feel I can't work on short fixed-term contracts. It is exhausting to wonder continuously whether the work will continue and what will happen to my family and I. If the university can't commit to me, I'm not ready or I can't even commit to the university as my employer. I am a highly educated woman, and my point of view is that my employer can't afford to act like this. As I'm aging, I'm starting to value or actually demand that my employer offers me some kind of continuity and vision for the future. I see the system, not the people, as the problem. Everyone working in a university understands what the problem is, but the system seems to be so inflexible and unworkable from the perspective of personnel management. My opinion is that the university can't afford this kind of personnel policy. (Senior researcher, female, 36)

Writing funding applications and proving one's skills constantly causes extra workload. Applying for external funding is based on very hard competition and not everyone considers it worth of doing because of the bad odds of being successful. In the open question, most of the respondents mentioned dissatisfaction with uncertain future prospects, the workload, and the stress caused by strong competition and the need to seek funding.

The [problem is the] difficulties of predicting what is happening next and the workload. The workload comes from the need to prove your skills to apply for the next bit of contract. [I’ve taken] no concrete actions yet. (Postdoctoral researcher, male, 35)

[T] he continuation of the working contract is so precarious, and just right now it seems that it's not going to continue next year. To receive external funding is impossible due to the full-cost model. Only the Finnish Academy applications are 'worth it', but there's too much competition and that's why it's too uncertain to count your whole future on that. (Researcher, female, 35)

I've considered moving to teaching at a university of applied sciences due to a permanent employment contract and a better salary. (Postdoctoral researcher, female, 35)

Most of the researchers seem to be committed to their work and therefore the option of leaving university is possible only for them who have no other option. Many of the researchers have considered leaving the university, but the problem seems to be where to go. When researchers have invested in their careers and the hopes for proceeding in academia have been high, it might be a bitter choice to leave a university. The following quote describes the desperate feelings some researchers might have after having noticed that there is no place for them in academia.

[I would leave] out of desperation, really. I do believe my place is the university. I want to teach and do research - this is what I have been trained to do for more than a decade. It's very hard for me to picture myself outside academia. But I think it's rather likely that in the end there is no future for me here. (Postdoctoral researcher, 39, female)

\section{Discussion and conclusions}

In this article, we have considered the reciprocal commitment in academic careers because of the reciprocal nature of academic careers where both dimensions are significant: organisational and individual. Furthermore, when studying academic 
careers, the influence of discipline, cultural context, and global trends must be taken into account as well (Kaulisch and Enders 2005). In academia, the researcher's career success is a win-win situation: it benefits the researcher's own career as well as the organisation. As Baruch emphasises, the organisational commitment benefits both sides (1998).

The precarious working conditions specifically of junior academics might affect how attractive the academic career is seen (Huisman et al 2002). However, the short fixedterm contracts have always been a common way of becoming an academic and most of the $\mathrm{PhD}$ graduates should in fact find a job outside the academia after their graduation. Still the precarious working conditions and competition for funding in universities have accelerated due to overall development at a global and national level, such as due to the changes in the funding of higher education. This might have a negative effect on higher education, the quality of research and teaching, and the motivation of the researchers.

According to our empirical data, the university employees did not consider the nature of commitment as reciprocal. The offers of the organisations' do not meet the wants of employees in universities in many cases. Academic researchers in the data found their work meaningful in spite of some of its negative characteristics and they felt their work as vocation. However, over one third of our respondents in both categories felt unsure about the possibility to continue their careers in academia. Many of them had short fixed-term contracts that were in many cases shorter than one year. In addition, we found out that as many as about 40 percent of them had considered leaving their university. This research result is in line with the study of Kinman and Jones (2008). Also we found out that fixed-term researchers' perceptions about the continuation of their career at their university were connected to how meaningful they found their work. That indicates the importance of reciprocal commitment and how the precarious working conditions may decrease the working motivation of the employees.

Our study raises new avenues for future research in order to better understand the reciprocity and the interaction in an academic career and academic work. We would like to suggest that future research focuses more on reflecting on what is an academic career and what kind of an employer is the university? We would also like to propose that the nature of reciprocity and interaction taking between the university and academics should be researched in more details. We hope that our research has managed to show that reciprocity is an important new perspective to study topics related to academic work, academic careers and to the relationships between academics and universities.

\section{Biographical notes on contributors}

Taru Siekkinen is a project researcher and a doctoral student at the Finnish Institute for Educational Research, University of Jyväskylä. Kari Kuoppala was a researcher in the School of Management, University of Tampere. Elias Pekkola is a lecturer in the School Management, University of Tampere. Jussi Välimaa is a professor of Higher Education, working at the Finnish Institute for Educational Research, University of Jyväskylä.

\section{Funding}

This article is based on two research projects funded by the Finnish Work Environment Fund in years 2013-2016.

\section{References}


Aarrevaara T., and Pekkola E. 2012. "A Comparative Perspective on the Work Content of the Academic Profession.” In Higher Education Research in Finland: Emerging Structures and Contemporary Issues, edited by A. Sakari, and D. M. Hoffman, 251270. Jyväskylä: University of Jyväskylä. Finnish Institute for Educational Research.

Baruch, J. 2013. "Careers in Academe: The Academic Labour Market As an EcoSystem.” Career Development International 18(2): 196-210.

Baruch, Y. 1998. "The Rise and Fall of Organisational Commitment.” Human Systems Management 17(2): 135-143.

Baruch, Y. 2004. Managing Careers: Theory and Practice. Harlow. FT Prentice Hall. Pearson Education Limited.

Baruch, Y. and Hall, D.T. 2004. "The Academic Career: A Model for Future Careers in Other Sectors?” Journal of Vocational Behaviour 64(2): 241-262.

Birnbaum, R. (1988). How Colleges Work: The Cybernetics of Academic Organization and Leadership. San Francisco: Jossey-Bass.

Brechelmacher, A., Park, E., Ates, G., Campbell, D., and F. J. 2015. “The Rocky Road to Tenure - Career Paths in Academia.” In Academic Work and Careers in Europe: Trends, Challenges, Perspectives, edited by T. Fumasoli, G. Goastellec, and B. M. Kehm, Springer. The changing academy - The changing academic profession in international comparative perspective.

Clark, B. 1983. The Higher Education System. Academic Organisation in Crossnational Perspective. Berkeley: University of California Press.

Clark, B. R. 2004. Sustaining change in universities: Continuities in case studies and concepts. Maidenhead: Open University Press.

Clark, B. R. 1998. Creating entrepreneurial universities: Organisational pathways of transformation. Oxford: Elsevier.

Cohen, A. 2007. "Commitment Before and After: An Evaluation and Reconceptualization of Organisational Commitment.” Human Resource Management Review 2007(17): 336-354.

Dale, A. 2009. “Quality Issues with Survey Research.” In Vol. 1 of The Secondary Analysis of Survey Data. London: Sage.

European Commission. 2008. Better Careers and More Mobility: A European Partnership for Researchers, SEC(2008)1911, Brussels, 23.5.2008 COM(2008)317 final.

European Commission. 2015. EURAXESS Researchers in Motion. Human Resource Excellence in Research. http://ec.europa.eu/euraxess/index.cfm/rights/index.

European Science Foundation. 2009. Research Careers in Europe. Landscape and Horizons. A Report by the ESF Member Organisation Forum on Research Career. http://www.esf.org/fileadmin/links/CEO/ResearchCareers_60p\%20A4_13Jan.pdf

Etzkowitz, H. 2013”Anatomy of the entrepreneurial university”. Social Science Information. 52 (3): 486-511. DOI: 10.1177/0539018413485832.

Farnham, D. 1999. Managing Universities and Regulating Academic Labour Markets. In: Farnhamn, D. (edit.), Managing Academic Staff in Changing University Systems, International Trends and Comparisons. Buckingham: The Society for Research into Higher Education \& Open University Press.

Feldt, T., Hyvönen, K., Mäkikangas, A., Rantanen, J., Huhtala, M. and Kinnunen, U. 2016. "Overcommitment as a predictor of effort-reward imbalance: evidence from an 8-year follow-up study". Scandinavian Journal of Work, Environment \& Health. Online firs-article. DOI: 10.5271/sjweh.3575. 
Fumasoli, T., Goastellec, G., and Kehm, B. M. 2015. Academic Work and Careers in

Europe: Trends, Challenges, Perspectives. The Changing Academy - The

Changing Academic Profession in International Perspective 12. Springer.

Hakala, J. 2009. "The Future of the Academic Calling? Junior Researchers in the Entrepreneurial University.” Higher Education 57:173-190.

Hakanen, J., and Koivumäki, J. 2014. "Engaged or Exhausted How Does It Affect Dentists’ Clinical Productivity?” Burnout Research, 2014 (1): 12-18.

Harley, S., Muller-Camen, M., and Collin, A. 2004. "From Academic Communities to Managed Organisations: The Implications for Academic Careers in UK and German Universities.” Journal of Vocational Behavior 64: 329-345.

Herriot, P., and Pemberton, C. 1996. “Contracting Careers.” Human Relations 49, 6.

Horta, H., Veloso, F. M., and Grediaga, R. 2010. "Navel Gazing: Academic Inbreeding and Scientific Productivity.” Management Science 56(3): 414-429.

Huisman, J., de Weert, E., and Bartelse, J. 2002. "Academic Careers from a European Perspective: The Declining Desirability of the Faculty Position.” The Journal of Higher Education 73(1): 141-160.

Hyde, A., Clarke, M., and Drennan, J. 2013. The Changing Role of Academics and the Rise of Managerialism. In The Academic Profession in Europe: New Tasks and New Challenges. The Changing Academy - The Changing Academic Profession in International Comparative Perspective, edited by B. M. Kehm and U. Teichler 5. Springer.

Kalleberg, A.L.2009. ”Precarious Work, Insecure Workers: Employment Relations in Transition”. American Sociological Review 74 (1):1-22.

Kallio, K-M., and Kallio, T. 2014. "Management-by-Results and Performance Measurement in Universities - Implications for Work Motivation.” Studies in Higher Education 39(4): 574-589.

Kaulisch, M., and Enders, J. 2005. "Careers in Overlapping Institutional Context. The Case of Academe.” Career Development International 10(2): 130-144.

Kinman, G. and Jones, F. 2008. "A life beyond work? Job demands, work-life balance, and wellbeing in UK academics". Journal of Human Behavior in the Social Environment 17:1-2:41-60. DOI: 10.1080/10911350802165478

Kogan, M., Moses, I., and El-Khawas, E. 1994. Staffing Higher Education: Meeting New Challenges. OECD. Higher Education Policy Series, No. 27. London, England: Jessica Kingsley.

Kogan, M and Teichler, U. 2007. "Key Challenges to Academic profession and its Interface with management: Some Introductory Thoughts. In Kogan, M. and Teichler, U. (eds.) Key Challenges to the Academic Profession. International Center for Higher Education Research Kassel. INCHER - Kassel. Paris and Kassel.

Kuoppala, K. Pekkola, E. Kivistö, J., Siekkinen, T. and Hölttä, S. eds. 2015. Tietoyhteiskunnan työläinen - suomalaisen akateemisen projektitutkijan työ ja toimintaympäristö. Tampere. Tampere University Press.

Mamia, T., and Koivumäki, J. 2007. "Reciprocity as a Source of Vertical Trust and Commitment to Organisation.” In Tietoyhteiskunta ja työorganisaatioiden muutos. Sosiologian tutkimuksia A 30, Turun yliopisto, sosiologian laitos, edited by T. Mamia, and H. Melin. Turku: Uniprint.

MEC. 2008. The Four-Stage Research Career Model. Reports of the Ministry of Education, Finland.

Meyer, J. P., and Allen, N. J. 1991. "A Three-Component Conceptualization of Organisational Commitment.” Human Resource Management Review 1(1): 61-89. 
Meyer, J. P., and Herscovitch, L. 2001. "Commitment in the Workplace. Toward a General Model.” Human Resource Management Review 11: 299-326.

Mora, J. G. 2001. "Governance and Management in the New University.” Tertiary Education and Management 7(2): 95-110.

Musselin, C. 2013. "Redefinition of the Relationships Between Academics and Their University.” Higher Education 65: 25-37.

Musselin, C. 2007. ’Transformation of Academic Work: Facts and Analysis”. In Kogan, M. and Teichler, U. (eds.) Key Challenges to the Academic Profession. International Center for Higher Education Research Kassel. INCHER - Kassel. Paris and Kassel.

Musselin, C. 2010. The Market for Academics. Routledge. New York.

Pekkola, E. 2009. "Akateeminen professio Suomessa. Valtakeskittymä vai kolmen luokan työntekijöitä.” Politiikka 51:4, 268-290.

Pekkola, E. 2010. "Nuorten yliopistolaisten työn palkitsevuus ja sen vaikutus akateemisen uran houkuttelevuudelle.” Työelämäntutkimus 2010(2): 145-159.

Pekkola, E. 2014. Korkeakoulujen professio Suomessa - kehityskulkuja, käsitteitä ja ajankuvia. Akateeminen väitöskirja. Tampereen yliopisto, johtamiskorkeakoulu. Tampere University Press. Suomen Yliopistopaino Oy - Juvenes Print Tampere 2014.

Pekkola E., Kuoppala K. \& Lätti R. (2012) Akateemisesti tyypillinen epätyypillinen työ? In: Volanen M.-V. (edit.) Toiseksi paras? Tieteentekijät ja uusi yliopisto. Helsinki: Tieteentekijöiden liitto, 12-27.

Pietilä, M. 2015. “Tenure Track Career System as a Strategic Instrument for Academic Leaders.” European Journal of Higher Education. doi: 10.1080/21568235.2015.1046466.

Piñheiro, R., Geschwind, L,, Foss, H. H., Pekkola, E. (2015). “Academic Leadership in the Nordic Countries: Patterns of Gender Equality”. In Desivilya Syna Helena, Costea Carmen-Eugenia (eds.) Women's Voices in Management : Identifying Innovative and Responsible Solutions. London: Palgrave Macmillan.

Rasmussen, B. 2015. "From Collegial Organisation to Strategic Management of Resources: Changes in Recruitment in Norwegian University.” Sage Open. JulySeptember 2015: 1-11.

Rinne, R., and Jauhiainen, A. 2012. "In the Shifting Sands of Policy - University Academics' and Employees’ Views and Experiences of Finnish New Higher Education Policy.” In Higher Education Research in Finland. Emerging Structures and Contemporary Issues, edited by S. Ahola, and D. Hoffman, 89-110. Jyväskylä: Koulutuksen tutkimuslaitos.

Saarinen, T., and Välimaa, J. 2012. "Change as an Intellectual Device and as an Object of Research.” In Managing Reform in Universities. The Dynamics of Culture, Identity and Organisational Change, edited by B. Stensaker, J. Välimaa, and C. Sarrico, 41-60. Basingstoke: Palgrave Macmillan.

Siekkinen, T., Pekkola, E., and Kuoppala, K. 2015. “The EU Human Resource Strategy for Researchers and the Working Conditions of Finnish Fixed-Term Researchers.” Journal of the European Higher Education Area 2015(3): 111-142.

Slaughter, S., and Leslie, L. 1997. Academic Capitalism. Politics, Policies, and the Entrepreneurial University. Baltimore: Johns Hopkins University Press.

Stahl, G., Miller, E., and Tung, R. 2002. “Towards the Boundaryless Career: A Closer Look at the Expatriate Career Concept and the Perceived Implications of an International Assignment.” Journal of World Business 37(3): 216-227.

Van Maanen, J. 1977. "Introduction: The Promise of Career Studies.” In Organisational Careers: Some New Perspectives, edited by J. Van Maanen, 1-12. London: Wiley. 
Välimaa, J. 1998. Culture and identity in higher education research. Higher Education. 36, pp 119-138.

Välimaa, J. 2011. "Uusi yliopistolaki ja kansallisen yliopistolaitoksen yhtiöittäminen.” In Koulutus yhteiskunnan muutoksissa: jatkuvuuksia ja katkoksia, edited by J. Lasonen, and J. Ursin, s. 43-93. Jyväskylä: Suomen kasvatustieteellinen seura: Kasvatusalan tutkimuksia 53.

Välimaa, J., Stenvall, J., Siekkinen, T., Pekkola, E., Kivistö, J., Nokkala, T., Kuoppala, K., Aittola, H., and Ursin, J. 2016. Neliportaisen tutkijanuramallin arviointihankkeen loppuraportti [The Evaluation of the Four-Stage Career Model in Finnish Universities] Opetus- ja kulttuuriministeriön julkaisuja 2016. 